\title{
Spectral, Magnetic, Electrochemical, Photochemical, DNA Binding and Cleavage, Catalytic and Biological Studies of 2, 2'-Bipyridyl Based $d$ - $f$ Hetero Binuclear Gd(III) and $\mathrm{Cu}(\mathrm{II})$ Complexes $\uparrow$
}

\author{
A. VIJAYARAJ ${ }^{\mathrm{a}}$, R. PRABU ${ }^{\mathrm{a}}$, L. VIJAYALAKSHMI $^{\mathrm{b}}$ and V. NARAYANAN ${ }^{\mathrm{a}^{*}}$ \\ ${ }^{\text {a } D e p a r t m e n t ~ o f ~ I n o r g a n i c ~ C h e m i s t r y, ~ U n i v e r s i t y ~ o f ~ M a d r a s, ~ G u i n d y ~ C a m p u s, ~}$ \\ Chennai-600 025, India \\ ${ }^{\mathrm{b}}$ Vidhya Sagar Women's College, Chengalpattu, Kancheepuram-603211, India \\ vnnara@yahoo.co.in
}

Received 19 January 2013 / Accepted 15 February 2013

\begin{abstract}
The new series of the 2,2'-bipyridyl based $d-f$ hetero binuclear $\mathrm{Gd}(\mathrm{III})$ and $\mathrm{Cu}$ (II) were synthesizes by Schiff base condensation method using 2,2'-bipyridyl, 5-bromosalicylaldehyde and different secondary amines namely; diethylenetriamine, tris(2-aminoethyl)amine, triethylenetetramine, $N, N$-bis(3-aminopropyl)ethylenediamine and $N, N$-bis(aminopropyl)piperazine. The complexes have been characterized by elemental analyses, molar conductivity, IR spectroscopy, mass spectroscopy, NMR spectroscopy, electronic spectroscopy and cyclic voltammetry. The binuclear [GdCuL ${ }^{1-5}$ ] complexes show two irreversible one electron reduction processes in DMF, $0.1 \mathrm{M}$ TBAP. The magnetic susceptibility of the complexes was measured by VSM (Vibrating Sample Magnetometer). The $\left[\mathrm{GdCuL}^{5}\right]$ complex shows ferromagnetic interaction. The initial rate values for the oxidation of catechol to $o$-quinone by the binuclear $\left[\mathrm{GdCuL}^{1-5}\right]$ complexes show that as the chain length increases the activity also increases. Gadolinium complexes of macrocycle ligands have attracted much attention as fluorescent probes in biological system as luminescence label and as medical diagnostics. The complexes $\left[\mathrm{GdCuL}^{5}\right]$ and $\left[\mathrm{GdCuL}^{4}\right]$ show good binding propensity to calf thymus DNA. The complexes display significant oxidative cleavage of circular plasmid pBR322 DNA in the presence of mercaptoethanol using singlet oxygen as a reactive species.
\end{abstract}

Keywords: $d$ - $f$ Hetero binuclear complexes, Synthesis, Biological studies

\section{Introduction}

A wide assortment of Schiff Base 2,2'-bipyridyl based $d$ - $f$ hetero binuclear metal complexes can be utilized for the design of molecular ferromagnets, as catalysts for many Schiff Base reactions, models of reaction centers of optical materials, luminescence materials, DNA binding and cleavage reagents, metalloenzymes etc. $^{1-3}$. Transition metal complexes with tunable coordination environments and versatile spectral and electrochemical properties offer a great scope of design for species that are suitable for catecholase, DNA binding and cleavage activities ${ }^{4}$. Hence, the synthesis of symmetrical and unsymmetrical binuclear $\mathrm{Gd}(\mathrm{III}) \mathrm{Cu}(\mathrm{II})$ complexes has gained more attention in recent years.

$\dagger$ Presented to the National Conference on Chemistry Solutions at SRM University, India 
2,2'-Bipyridines (bpy) have been widely studied due to their predictable coordination behavior as well as their interesting electrochemical and photophysical properties ${ }^{5,6}$. $d-f \mathrm{Gd}(\mathrm{III}) \mathrm{Cu}(\mathrm{II})$ complexes have particularly drawn significant interest, since they are able to catalyze reduction and oxidation processes under visible light irradiation enclosing a broad range of substrates.

The spectroscopic tags and functional models for the active centers of proteins and metal complexes have helped elucidate the mechanisms by which metalloproteins function. Binucleating ligands are particularly suited for the synthesis of such complexes as they are more stable and the $\mathrm{Gd}(\mathrm{III})$ and $\mathrm{Cu}(\mathrm{II})$ metal ions are fixed in close proximity, which has important implications for metal-metal interactions and their reactivity ${ }^{7}$. These properties have turned chemical nucleases into useful tools as adjuvant in PCR diagnostics ${ }^{8}$ nucleic acid attacking and cleaving agents ${ }^{9}$.

Each of the $\mathrm{Gd}(\mathrm{III})$ and $\mathrm{Cu}(\mathrm{II})$ ions is in a different coordination environment, the $\mathrm{Gd}(\mathrm{III})$ ion is coordinated to acyclic imine compartment and $\mathrm{Cu}$ (II) ion coordinate to 2,2'-bipyridyl moieties.

We have already reported the mono nuclear acyclic Gd(III) complexes ${ }^{10}$. Herein, we report the synthesis of side-off unsymmetrical binuclear $\mathrm{Gd}(\mathrm{III})$ and $\mathrm{Cu}(\mathrm{II})$ complexes (Scheme 1) and their electrochemical, luminescence, magnetic, catecholase activity, DNA binding, DNA cleavage and anti-microbial studies.

\section{Experimental}

5-Bromosalicylaldehyde ${ }^{11}$ was prepared following the literature method. 2,2'-Bipyridyl, and gadolinium nitrate were purchased from Aldrich. Analytical grade methanol, acetonitrile and dimethyl formamide were purchased from Qualigens. TBAP used as supporting electrolyte in electrochemical measurements was purchased from Fluka and recrystallized from hot methanol. $N, N$-Bis-(3-aminopropyl) piperazine, $N, N$-bis-(3-aminopropyl) ethylene diamine and tris-(2-aminoethyl)amine were purchased from Aldrich. Triethylenetetramine, diethylenetriamine and copper carbonate were purchased from Qualigens.

\section{Analytical and physical measurements}

Elemental analysis of the complexes was obtained using a Haereus CHN rapid analyzer. Conductivity measurement of the complexes were measured using a Elico digital conductivity bridge model CM-88 using freshly prepared solution of the complex in DMF. The FT-IR spectra were recorded on a Perkin Elmer FT-IR 8300 series spectrophotometer on $\mathrm{KBr}$ discs from 4000 to $400 \mathrm{~cm}^{-1}$. Electronic spectral studies were carried out on a Perkin-Elmer UV-320 spectrophotometer from 200 to $1100 \mathrm{~nm}$. ESI Mass spectra were obtained on a JEOL DX-303 mass spectrometer. The concentration of the samples was about $1.0 \mu \mathrm{mol} \mathrm{dm}$. The diluted solutions were electro sprayed at a flow rate of $5 \times 10^{-6} \mathrm{dm}^{-3} \mathrm{~min}^{-1}$ with a needle voltage of $+4.5 \mathrm{kV}$. The mobile phase was an aqueous solution of methanol $(\mathrm{v} / \mathrm{v}, 1: 1)$ and the samples were run in the positive-ion mode. Steady state fluorescence measurements were carried out by using a fluorescence spectrophotometer (Fluoromax 4P, Horiba Jobin Yvon). The concentration of the stock solution was $3 \times 10^{-5} \mathrm{M}$ in DMF medium.

\section{General procedure for electrochemical studies}

The cyclic voltammetric experiments were performed on a CHI-600A electrochemical analyzer under oxygen free condition using a three-electrode cell in which a glassy carbon 
electrode was the working electrode, $\mathrm{Ag}-\mathrm{AgCl}$ as reference electrode and a platinum wire was the auxiliary electrode. The oxidation potential of ferrocene /ferrocenium $\left(\mathrm{Fc} / \mathrm{Fc}^{+}\right)$couple under the experimental condition was $470 \mathrm{mV}$. Tetra n-butyl ammonium perchlorate (TBAP) was used as the supporting electrolyte. Experiments were performed under a purified nitrogen atmosphere at $25 \pm 0.1{ }^{\circ} \mathrm{C}$. All the complex concentrations were $1.05 \times 10^{-3} \mathrm{~mol} \mathrm{dm}^{-3}$ in $0.1 \mathrm{~mol} \mathrm{dm}^{-3}$ TBAP (tetra-butyl ammonium perchlorate) DMF solutions. The solutions were deaerated for $c a$. 15 min before applying the voltage. The half wave potentials, $\mathrm{E}_{1 / 2}$, were calculated approximately from $\left(\mathrm{E}_{\mathrm{pa}+} \mathrm{E}_{\mathrm{pc}}\right) / 2$ and the measured errors were $\pm 2 \mathrm{mV}$.

\section{General procedure DNA cleavage studies}

The cleavage activity of complexes has been studied by agarose gel electrophoresis using pBR 322 DNA. The DNA was treated with the $\left[\mathrm{GdCuL}^{1-5}(\mathrm{bpy})_{2}\right]$ complexes in different concentrations $(20,40,60,80$ and $100 \mu \mathrm{M})$ fortified with $5 \mathrm{mM} \mathrm{H}_{2} \mathrm{O}_{2}, 100 \mathrm{mM}$ Tris-Hcl $(\mathrm{pH}$ 8.0) and $0.2 \mu \mathrm{g} / \mu \mathrm{L}$ of pBR 322 DNA. All the samples were incubated for $2 \mathrm{~h}$ at RT in both light and dark conditions. After the incubation period, the concentration of DNA was quantified using spectrophotometer and the results have expressed in $\mu \mathrm{g} / \mu \mathrm{L}$ units. The remaining samples have been loaded on $1 \%$ agarose gel using $1 \mu \mathrm{g} / \mathrm{mL}$ ethidium bromide and $6 \mathrm{X}$ gel loading buffer. The Electrophoresis was carried out for $1.5 \mathrm{~h}$ at $100 \mathrm{~V}$ in TBE buffer. Bands were visualized by UV light and photographed using Geldoc 100 (Biorad) system.

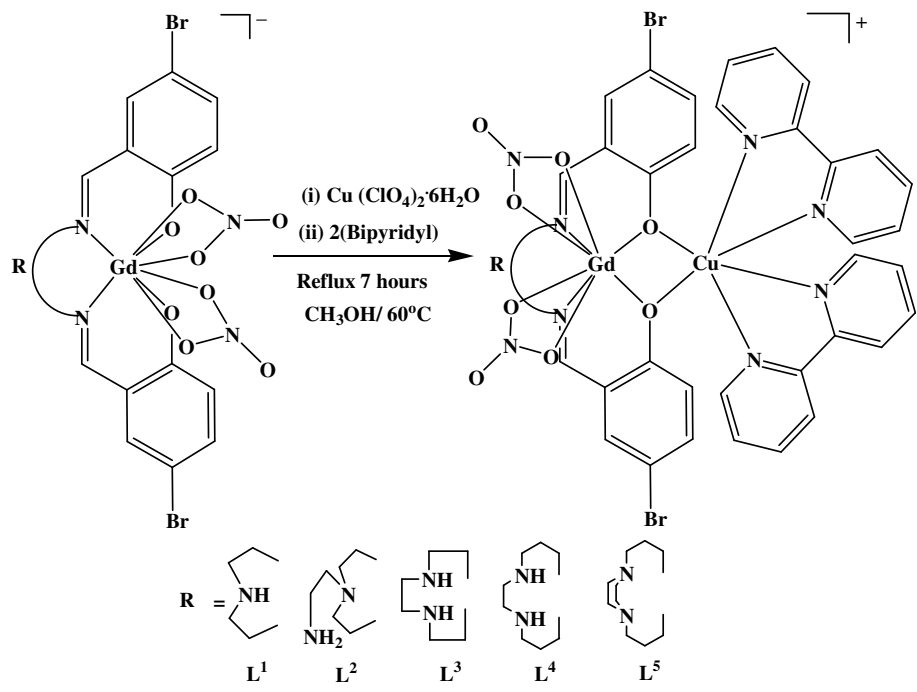

Scheme 1

\section{Synthesis of bipyridine based d-f hetero binuclear complexes}

The $d$-f binuclear complex was prepared from a general synthetic procedure in which an ethanolic solution of $\mathrm{Cu}\left(\mathrm{ClO}_{4}\right)_{2} \cdot 6 \mathrm{H}_{2} \mathrm{O}(0.0925 \mathrm{~g}, 0.25 \mathrm{mmol})$ was added slowly to a vigorously stirred suspension of the mononuclear $\mathrm{Gd}(\mathrm{III})$ complex $(0.25 \mathrm{mmol})$ in methanol $(10 \mathrm{~mL})$ and the mixture was stirred for $15 \mathrm{~min}$ to obtain a clear solution. Then an methanolic solution $(5 \mathrm{~mL})$ of 2,2-bipyridyl $(0.07809 \mathrm{~g}, 0.5 \mathrm{mmol})$ was added dropwise to the above solution and the resulting solution was stirred for $3 \mathrm{~h}$ at $25{ }^{\circ} \mathrm{C}$. A dark green colored solid was separated on evaporation of the solvent at ambient temperature and this was recrystallized from acetonitrile. 
[GdCuL $\left.{ }^{l}(\text { bpy })_{2}\left(\mathrm{NO}_{3}\right)_{2}\right]\left(\mathrm{ClO}_{4}\right)$ Yellowish green solid

Yield: $0.0680 \mathrm{~g}$, (51\%). Analytical data for $\left[\mathrm{C}_{38} \mathrm{H}_{32} \mathrm{ClBr}_{2} \mathrm{~N}_{9} \mathrm{O}_{12} \mathrm{CuGd}\right]$; M.Wt: 1222.77 Calculated (\%): C, 40.63; H, 2.87; N, 11.22; Cu, 5.64; Gd, 14.00; Found (\%): C, 40.61; H, 2.86; N, 11.20; Cu, 5.66; Gd, 13.95; Selected IR $\left(\mathrm{KBr}, \mathrm{cm}^{-1}\right) 1630 \mathrm{~s}[v(\mathrm{C}=\mathrm{N})] ; 1532 \mathrm{~s}[v(\mathrm{C}-$ $\mathrm{O})] ; 1125 \mathrm{~s}\left[v\left(\mathrm{NO}_{3}{ }^{-}\right] ; 1010 \mathrm{w}\right.$ [ $v\left(\mathrm{ClO}_{4}^{-}\right)$uncoordinated]; $610 \mathrm{~m}[v(\mathrm{M}-\mathrm{O})]$; ESI- MS $(\mathrm{m} / \mathrm{z})(\%)$ : $\left[\mathrm{GdCuL}^{1 \mathrm{~b}}(\mathrm{bpy})_{2}\left(\mathrm{NO}_{3}\right)_{2}\right]^{+}: 1121.92\left[\mathrm{MH}^{-}\right]$, Calcd $(\mathrm{m} / z) 1123.32$; UV-Vis $\left[\lambda_{\max }, \mathrm{nm}\left(\varepsilon, \mathrm{M}^{-1} \mathrm{~cm}^{-1}\right)\right]$ in DMF: 573(166) 361 (17586) 247 (23486); Conductance $\left(\Lambda_{\mathrm{m}}, \mathrm{S} \mathrm{cm}^{2} \mathrm{~mol}^{-1}\right)$ in DMF: 132.

$\left[\mathrm{GdCuL}{ }^{2}(\mathrm{bpy})_{2}\left(\mathrm{NO}_{3}\right)\right]\left(\mathrm{ClO}_{4}\right)_{2}$ Yellowish green solid

Yield: $0.065 \mathrm{~g},(54 \%)$. Analytical data for $\left[\mathrm{C}_{40} \mathrm{H}_{38} \mathrm{Cl}_{2} \mathrm{Br}_{2} \mathrm{~N}_{9} \mathrm{O}_{13} \mathrm{CuGd}\right]$; M.Wt: 1304.29 Calculated (\%): C, 43.46; H, 3.46; N, 11.40; Cu, 5.75; Gd, 14.23; Found (\%): C, 43.43; H, 3.44; N, 11.36; $\mathrm{Cu}, 5.76 ; \mathrm{Gd}, 14.20$; Selected IR $\left(\mathrm{KBr}, \mathrm{cm}^{-1}\right) 1640 \mathrm{~s}[v(\mathrm{C}=\mathrm{N})] ; 1556 \mathrm{~s}[v(\mathrm{C}-\mathrm{O})]$; $1134 \mathrm{~s}\left[v\left(\mathrm{NO}_{3}^{-}\right] ; 1087 \mathrm{w}\right.$ [ $v\left(\mathrm{ClO}_{4}^{-}\right)$uncoordinated]; $632 \mathrm{~m}[v(\mathrm{M}-\mathrm{O})]$; ESI- MS $(\mathrm{m} / \mathrm{z})(\%)$ : $\left[\mathrm{GdCuL}^{2 \mathrm{~b}}(\mathrm{bpy})_{2}\left(\mathrm{NO}_{3}\right)\right]^{2+}: 552.69\left[\mathrm{MH}^{-}\right]$,Calcd av. $(\mathrm{m} / \mathrm{z}) 1105.39$; UV-Vis $\left[\lambda_{\max }, \mathrm{nm}\left(\varepsilon, \mathrm{M}^{-1} \mathrm{~cm}^{-1}\right)\right]$ in DMF: 579(157) 369 (17187) 261 (22786); Conductance $\left(\Lambda_{\mathrm{m}}, \mathrm{S} \mathrm{cm}^{2} \mathrm{~mol}^{-1}\right)$ in DMF: 186.

$\left[\mathrm{GdCuL}^{3}(\mathrm{bpy})_{2}\left(\mathrm{NO}_{3}\right)\right]\left(\mathrm{ClO}_{4}\right)_{2}$ Yellowish green solid

Yield: $0.079 \mathrm{~g},(51 \%)$. Analytical data for $\left[\mathrm{C}_{40} \mathrm{H}_{36} \mathrm{Cl}_{2} \mathrm{Br}_{2} \mathrm{~N}_{9} \mathrm{O}_{13} \mathrm{CuGd}\right]$; M.Wt: 1302.28 Calculated (\%): C, 43.54; H, 3.29; N, 11.42; Cu, 5.76; Gd, 14.25; Found (\%): C, 43.53; H, 3.27; N, 11.40; Cu, 5.76; Gd, 14.23; Selected IR $\left(\mathrm{KBr}, \mathrm{cm}^{-1}\right) 1641 \mathrm{~s}[v(\mathrm{C}=\mathrm{N})] ; 1562 \mathrm{~s}[v(\mathrm{C}-$ $\mathrm{O})] ; 1145\left[v\left(\mathrm{NO}_{3}^{-}\right] ; 1098 \mathrm{w}\right.$ [ $v\left(\mathrm{ClO}_{4}^{-}\right)$uncoordinated]; $631 \mathrm{~m}[v(\mathrm{M}-\mathrm{O})]$; ESI- MS $(\mathrm{m} / \mathrm{z})(\%)$ : $\left[\mathrm{GdCuL}^{3 \mathrm{~b}}(\mathrm{bpy})_{2}\left(\mathrm{NO}_{3}\right)\right]^{2+}: 551.69\left[\mathrm{MH}^{-}\right]$, Calcd $(\mathrm{m} / z) 1103.38 ; \mathrm{UV}-\mathrm{Vis}\left[\lambda_{\max }, \mathrm{nm}\left(\varepsilon, \mathrm{M}^{-1} \mathrm{~cm}^{-1}\right)\right]$ in DMF: 583(154) 374 (16937) 281 (21786); Conductance $\left(\Lambda_{\mathrm{m}}, \mathrm{S} \mathrm{cm}^{2} \mathrm{~mol}^{-1}\right)$ in DMF: 173.

$\left[\mathrm{GdCuL}{ }^{4}(\mathrm{bpy})_{2}\left(\mathrm{NO}_{3}\right)\right]\left(\mathrm{ClO}_{4}\right)_{2}$ Yellowish green solid

Yield: $0.083 \mathrm{~g}$, (57\%).Analytical data for $\left[\mathrm{C}_{42} \mathrm{H}_{40} \mathrm{Cl}_{2} \mathrm{Br}_{2} \mathrm{~N}_{9} \mathrm{O}_{13} \mathrm{CuGd}\right]$; M.Wt: 1330.33 Calculated (\%): C, 44.59; H, 3.56; N, 11.14; Cu, 5.62; Gd, 13.90; Found (\%): C, 44.57; H, 3.55; $\mathrm{N}, 11.12 ; \mathrm{Cu}, 5.60 ; \mathrm{Gd}, 13.89$; Selected IR $\left(\mathrm{KBr}, \mathrm{cm}^{-1}\right) 1630 \mathrm{~s}[v(\mathrm{C}=\mathrm{N})] ; 1530 \mathrm{~s}[v(\mathrm{C}-\mathrm{O})]$; $1140 \mathrm{~s}\left[v\left(\mathrm{NO}_{3}{ }^{-}\right] ; 1087 \mathrm{w}\left[v\left(\mathrm{ClO}_{4}^{-}\right)\right.\right.$uncoordinated] ; $\left.628 \mathrm{~m} \mathrm{[v}(\mathrm{M}-\mathrm{O})\right]$; ESI- MS $(\mathrm{m} / \mathrm{z})(\%)$ : $\left[\mathrm{GdCuL}^{4 \mathrm{~b}}(\mathrm{bpy})_{2}\left(\mathrm{NO}_{3}\right)\right]^{2+}: 564.71\left[\mathrm{MH}^{-}\right]$, Calcd $(\mathrm{m} / \mathrm{z}) 1131.43 ; \mathrm{UV}-\mathrm{Vis}\left[\lambda_{\max }, \mathrm{nm}\left(\varepsilon, \mathrm{M}^{-1} \mathrm{~cm}^{-1}\right)\right]$ in DMF: 591(146) 381 (16587) 287 (21486); Conductance $\left(\Lambda_{\mathrm{m}}, \mathrm{S} \mathrm{cm}^{2} \mathrm{~mol}^{-1}\right)$ in DMF: 165.

$\left[\mathrm{GdCuL}{ }^{5}(\mathrm{bpy})_{2}\left(\mathrm{NO}_{3}\right)\right]\left(\mathrm{ClO}_{4}\right)_{2}$ green solid

Yield: $0.087 \mathrm{~g},(51 \%)$. Analytical data for $\left[\mathrm{C}_{44} \mathrm{H}_{44} \mathrm{Cl}_{2} \mathrm{Br}_{2} \mathrm{~N}_{9} \mathrm{O}_{13} \mathrm{CuGd}\right]$; M.Wt: 1358.38; Calculated (\%): C, 45.58; H, 3.82; N, 10.87; Cu, 5.48; Gd, 13.56; Found (\%): C, 45.55; H, 3.80; N, 10.85; Cu, 5.47; Gd, 13.54; Selected IR $\left(\mathrm{KBr}, \mathrm{cm}^{-1}\right) 1634 \mathrm{~s}[v(\mathrm{C}=\mathrm{N})]$; $1544 \mathrm{~s}[v(\mathrm{C}-$ $\mathrm{O})] ; 1145 \mathrm{~s}\left[v\left(\mathrm{NO}_{3}{ }^{-}\right] ; 1082 \mathrm{w}\right.$ [ $v\left(\mathrm{ClO}_{4}^{-}\right)$uncoordinated]; $687 \mathrm{~m}[v(\mathrm{M}-\mathrm{O})]$; ESI- MS $(\mathrm{m} / \mathrm{z})(\%)$ : $\left[\mathrm{GdCuL}^{5 \mathrm{~b}}(\mathrm{bpy})_{2}\left(\mathrm{NO}_{3}\right)\right]^{2+}: 578.74\left[\mathrm{MH}^{-}\right]$, Calcd $(\mathrm{m} / \mathrm{z}) 1159.48 ; \mathrm{UV}-\mathrm{Vis}\left[\lambda_{\max }, \mathrm{nm}\left(\varepsilon, \mathrm{M}^{-1} \mathrm{~cm}^{-1}\right)\right]$ in DMF: 610 (139) 394 (15937) 294 (21136); Conductance $\left(\Lambda_{\mathrm{m}}, \mathrm{S} \mathrm{cm}^{2} \mathrm{~mol}^{-1}\right)$ in DMF: 181.

\section{Results and Discussion}

\section{IR spectra}

The IR spectra of the complexes show all the expected bands for coordinated Schiff base type (bpy) ligands. The bands at $1580 \mathrm{~cm}^{-1}$ and $1240 \mathrm{~cm}^{-1}$ are assigned to coordinated $\mathrm{C}=\mathrm{N}-$ and $\mathrm{C}-\mathrm{O}-$ stretchings, respectively. Coordination of the ligand to the metal through the imine nitrogen and phenolic $\mathrm{C}-\mathrm{O}-$ is expected to reduce the electron density in the imine nitrogen and lower $v(\mathrm{C}=\mathrm{N})$ to $1619 \mathrm{~cm}^{-1}$ and phenolic $(\mathrm{C}-\mathrm{O}-) 1240 \mathrm{~cm}^{-1}$ that showed that 
the imine nitrogen of the ligand is strongly coordinated to the metal center ${ }^{12}$. A medium intensity band, at $3330 \mathrm{~cm}^{-1}$ in the free ligand due to $v(\mathrm{OH})$ was absent in the complex, indicating deprotonation of the ligand prior to coordination ${ }^{13}$. For the complexes, bands at $430-466 \mathrm{~cm}^{-1}$ could be assigned to -(M-O) bond. Sharp peaks observed around $1330-1400 \mathrm{~cm}^{-}$ ${ }^{1}$ are assigned due to $v\left(\mathrm{Gd}-\mathrm{NO}_{3}\right)$ in the complexes ${ }^{14}$. Other weak bands at lower frequency could be assigned to $-(\mathrm{M}-\mathrm{N})$ bond. The spectra of all the complexes are dominated by bands at $3150-3070 \mathrm{~cm}^{-1}$ due to the aromatic $\mathrm{C}-\mathrm{H}$ stretching vibration ${ }^{15}$. The presence of uncoordinated perchlorate anions in all of the binuclear complexes are inferred from a single broad band around $1100 \mathrm{~cm}^{-1}$ ( $v_{3}$-antisymmetric stretching) which are not split and a band around $650 \mathrm{~cm}^{-1}$ ( $v_{4}$-antisymmetric bending).

\section{ESI mass spectral analysis}

The ESI mass spectra of binuclear complexes $\left[\mathrm{GdCuL}^{5}(\mathrm{bpy})_{2}\left(\mathrm{NO}_{3}\right)\right]\left(\mathrm{ClO}_{4}\right)_{2}$, show the parent ion peak $\left(\mathrm{M}^{\mathrm{n}+}\right)$ at $(\mathrm{m} / \mathrm{z})=578.33$ respectively. The spectra show some prominent peaks corresponding to the various fragments of the complexes. The ESI mass spectra of binuclear complexes $\left[\mathrm{GdCuL}^{5}(\mathrm{bpy})_{2}\left(\mathrm{NO}_{3}\right)\right]\left(\mathrm{ClO}_{4}\right)_{2}$ are shown in Figure 1.

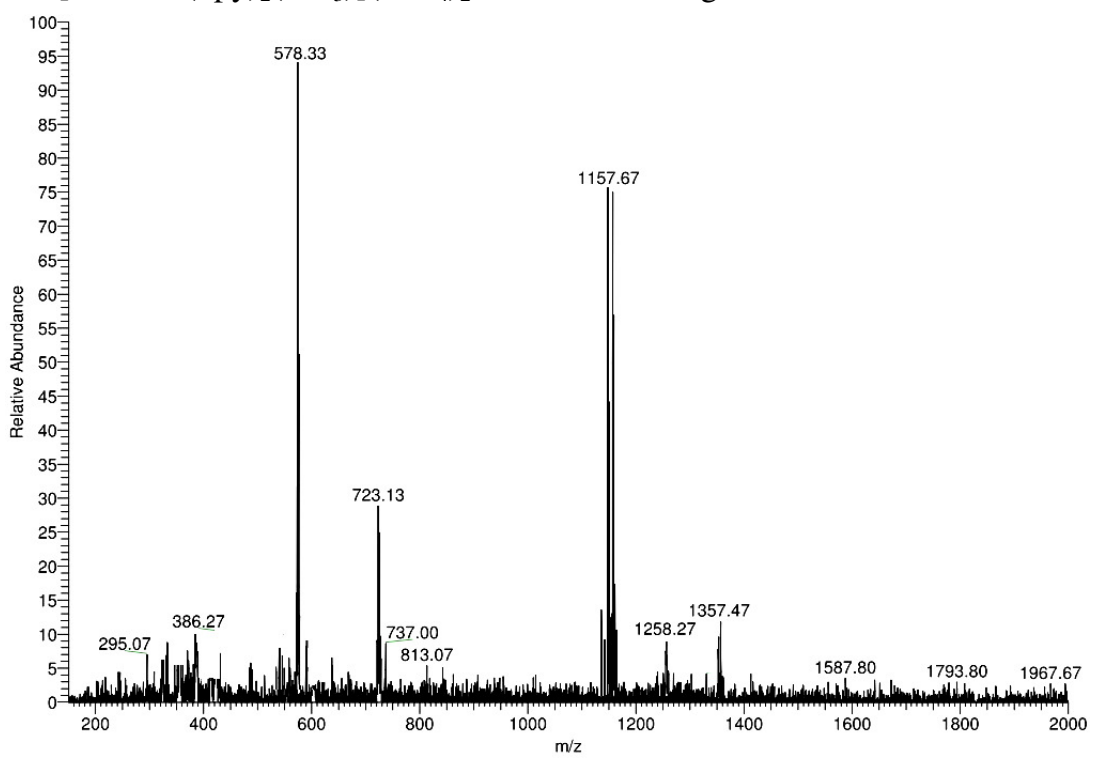

Figure 1. ESI Mass spectrum of: $\left[\mathrm{GdCuL}^{5}(\mathrm{bpy})_{2}\left(\mathrm{NO}_{3}\right)\right]$

\section{Electronic spectra of $\left[\mathrm{Gd}(\mathrm{III}) \mathrm{Cu}(\mathrm{II}) \mathrm{L}^{\mathrm{I-5}}(\text { bpy })_{2}\left(\mathrm{NO}_{3}\right)\right]$ complexes}

Electronic spectra of all the complexes were obtained in DMF medium. The electronic spectra of all the complexes show a single weak d-d band in the region 573-610 $\mathrm{nm}$ due to $\mathrm{d}_{\mathrm{x}-\mathrm{y}}^{2} \rightarrow \mathrm{d}_{\mathrm{xy} y \mathrm{y}} ; \mathrm{d}_{\mathrm{z}}{ }^{2} ; \mathrm{d}_{\mathrm{xy}}$ associated with distorted octahedral geometry around the $\mathrm{Cu}(\mathrm{II})$ ion. A red shift in the $\lambda_{\max }$ value of d-d band width increase in the chain length between imine nitrogen has been observed. This red shift may be due to the distortion from planar geometry as the chain length increases. Moderately intense band observed in the region of 361-394 nm is associated with ligand to metal charge transfer transition ${ }^{16,17}$. The peak in the range of 247-294 $\mathrm{nm}$ is assigned to the intra ligand transition $\left(\pi-\pi^{*}\right)$. Electronic spectra of all the hetero binuclear $\left[\mathrm{GdCuL}^{1-5}(\mathrm{bpy})_{2}\right]$ complexes are given in Figure $2 \& 3$. Electronic spectral data for all binuclear $\left[\mathrm{Gd}(\mathrm{III}) \mathrm{Cu}(\mathrm{II}) \mathrm{L}^{1-5}\right]$ complexes are given in Table 1. 


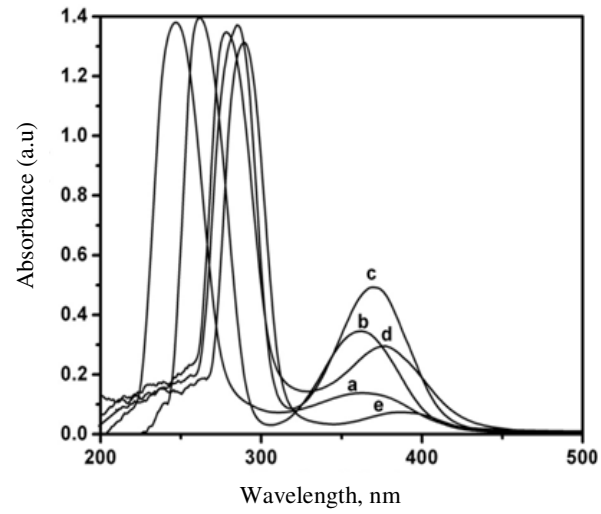

Figure 2. Electronic spectra of: $\left[\mathrm{GdCuL}^{1-5}\right.$ (bpy $)_{2}$ ] complexes

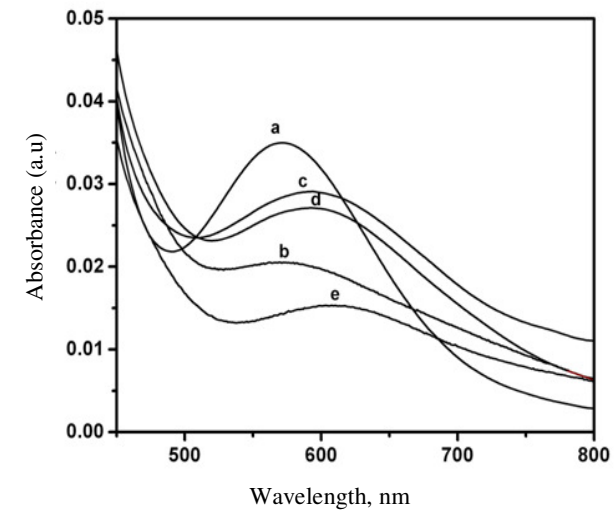

Figure 3. (a) $\left[\mathrm{GdCuL}^{1}(\mathrm{bpy})_{2}\right],(\mathrm{b})\left[\mathrm{GdCuL}^{2}\right.$ (bpy $\left.)_{2}\right], \quad(\mathrm{c})\left[\mathrm{GdCuL}^{3}(\mathrm{bpy})_{2}\right], \quad(\mathrm{d})\left[\mathrm{GdCuL}^{4}\right.$ (bpy)] and (e) $\left[\mathrm{GdCuL}^{5}(\mathrm{bpy})_{2}\right]$

Table 1. Electronic spectral data of $\left[\mathrm{GdCuL}^{1-5}\left(\mathrm{NO}_{3}\right)(\mathrm{bpy})_{2}\right]$

\begin{tabular}{cccc}
\hline \multirow{2}{*}{ No } & \multirow{2}{*}{ Complexes } & \multicolumn{2}{c}{$\lambda_{\max }, \mathrm{nm}, \varepsilon / \mathrm{M}^{-1} \mathrm{~cm}^{-1}$} \\
\cline { 3 - 4 } & & $\mathrm{d}-\mathrm{d}$ & \multicolumn{2}{c}{ charge transfer } \\
\hline 1. & {$\left[\mathrm{GdCuL}^{1}\right]$} & $573(166)$ & $361(17586) 247(23486)$ \\
2. & {$\left[\mathrm{GdCuL}^{2}\right]$} & $579(157)$ & $369(17187) 261(22786)$ \\
3. & {$\left[\mathrm{GdCuL}^{3}\right]$} & $583(154)$ & $374(16937) 281(21786)$ \\
4. & {$\left[\mathrm{GdCuL}^{4}\right]$} & $591(146)$ & $381(16587) 287(21486)$ \\
5. & {$\left[\mathrm{GdCuL}^{5}\right]$} & $610(139)$ & $394(15937) 294(21136)$ \\
\hline
\end{tabular}

\section{Fluorescence spectra}

Emission spectra of complexes $\left[\mathrm{GdCuL}^{1-5}\right]$ in DMF solution with excitation at $460 \mathrm{~nm}$ were shown in Figure 4. The fluorescence characteristics complexes were determined. The luminescence of $\mathrm{Ln}^{3+}$ chelates is related to the efficiency of the intramolecular energy transfer between the triplet levels of the ligand and the emitting level of the ions, which depends on the energy gap between the two levels. In the intramolecular energy transfer, triplet state energy of the ligand is regarded as an important factor in excitation of the lanthanide ion ${ }^{18,19}$. Compared with complex $3\left[\mathrm{GdCuL}^{3}\right]$, there is lower emission band in the range 400-700 $\mathrm{nm}$ indicating the fluorescence of $\mathrm{Gd}, \mathrm{Cu}$ ion in the cavity was completely quenched ${ }^{20-22}$ by the $\mathrm{L}^{3}$. But emission band in the range 430-700 nm $\left[\mathrm{GdCuL}^{1,2,4,5}\right]$ having higher emission intensity. However, the characteristic emission spectrum of $\left[\mathrm{GdCuL}^{1-5}\right]$ was observed. All emissions arise from the ${ }^{6} \mathrm{D}_{\mathrm{j}}$ level corresponding to the ${ }^{8} \mathrm{~S}_{7 / 2} \leftarrow{ }^{6} \mathrm{D}_{\mathrm{j}}$ transition. The weak band at $490 \mathrm{~nm}$ arises from the ${ }^{8} \mathrm{~S}_{7 / 2}$ $\leftarrow{ }^{6} \mathrm{D}_{\mathrm{j}}$ transition. The band around $470 \mathrm{~nm}$ for ${ }^{8} \mathrm{~S}_{7 / 2} \leftarrow{ }^{6} \mathrm{D}_{\mathrm{j}}$, which is magnetic-dipole allowed, is hardly affected by a change of the coordination environment. The intense band around $500 \mathrm{~nm}$ for ${ }^{8} \mathrm{~S}_{7 / 2} \leftarrow{ }^{6} \mathrm{D}_{\mathrm{j}}$ is an electric-dipole allowed transition and its emission intensity is sensitive to the coordination environment of $\mathrm{Gd}(\mathrm{III})$. This shows that fluorescence emission of Gd(III) ions in the complex was influenced by the ligand center.

\section{Cyclic voltammetric behavior}

The cyclic voltammograms of binuclear complexes, $\left[\mathrm{GdCuL}^{1-5}(\mathrm{bpy})_{2}\left(\mathrm{NO}_{3}\right)\right]$ recorded in DMF medium in the range 0.0 to $-2.25 \mathrm{~V}$ at the scan rate of $0.05 \mathrm{~V} \mathrm{~s}^{-1}$ are given in Figure 5 . 
Complex $\left[\mathrm{GdCuL}^{1}\right]$ shows well defined two cathodic peak potential of $\mathrm{E}_{\mathrm{pc}}^{1}=-1.05 \mathrm{~V}$ and $\mathrm{E}_{\mathrm{pc}}^{2}=-1.90 \mathrm{~V}(\mathrm{Ag} / \mathrm{AgCl})$ respectively. The first reduction process is $\mathrm{Cu}(\mathrm{II}) / \mathrm{Cu}(\mathrm{I})$. The second reduction process observed at the cathodic potentials $\mathrm{E}_{\mathrm{pc}}^{2}-1.90 \mathrm{~V}$, which may be corresponding to the mono nuclear complex $\left[\mathrm{Gd}(\mathrm{III}) \mathrm{L}^{1}\right]$ peak potential is ligand centered. The overall electrode reaction is suggested to be $\mathrm{LGd}(\mathrm{III}) \mathrm{Cu}(\mathrm{II}) / \mathrm{LGd}(\mathrm{III}) \mathrm{Cu}(\mathrm{I})$ $/ \mathrm{L}^{\circ} \mathrm{Gd}(\mathrm{III}) \mathrm{Cu}(\mathrm{I})$. The electrochemical data for all the complexes are given in Table 2 . For the complexes $\left[\mathrm{GdCuL}^{1}\right]$ to $\left[\mathrm{GdCuL}^{5}\right]$ the reduction potential values shift to more negative potential. This may be due to increasing the chain length and as a result the entire cyclic ring becomes more flexible, which causes a distortion of the geometry of the $\left[\mathrm{GdCuL}^{1-5}\right]$ complexes and makes the system more flexible. The cyclic voltammogram are shown in Figure 5. The reduction process is as follows;

$\mathrm{Gd}(\mathrm{III}) \mathrm{Cu}(\mathrm{II}) \mathrm{L} \rightarrow \mathrm{Gd}(\mathrm{III}) \mathrm{Cu}(\mathrm{I}) \mathrm{L} \rightarrow \mathrm{Gd}(\mathrm{III}) \mathrm{Cu}(\mathrm{I}) \mathrm{L}^{\bullet}$

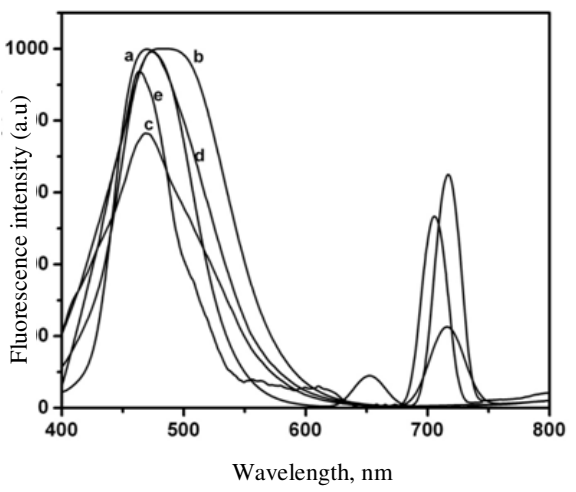

Figure 4. Luminescence spectra of: $\left[\mathrm{GdCuL}^{1-5}(\mathrm{bpy})_{2}\right] \quad$ complexes (a) $\left[\mathrm{GdCuL}^{1}(\mathrm{bpy})_{2}\right]$, (b) $\left[\mathrm{GdCuL}^{2}(\mathrm{bpy})_{2}\right]$, (c) $\left[\mathrm{GdCuL}^{3}(\mathrm{bpy})_{2}\right]$, (d) $\left[\mathrm{GdCuL}^{4}\right.$ (bpy)] and (e) $\left[\mathrm{GdCuL}^{5}(\mathrm{bpy})_{2}\right]$

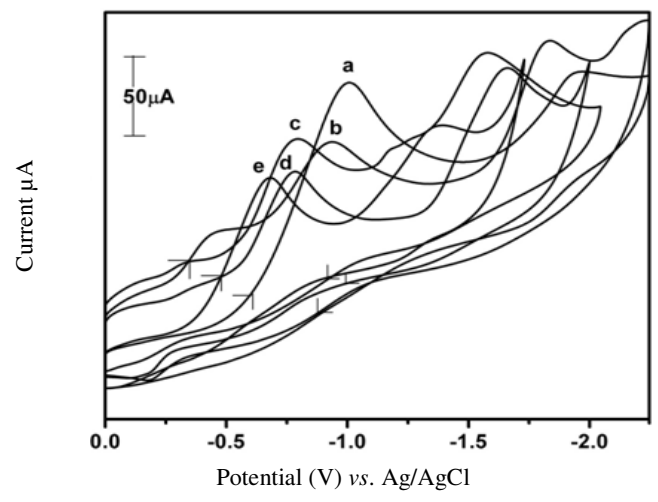

Figure 5. Cyclic voltammogram of:

(a) $\left[\mathrm{GdCuL}^{1-5}(\mathrm{bpy})_{2}\right]$ complexes (a) $\left[\mathrm{GdCuL}^{1}(\mathrm{bpy})_{2}\right]$, (b) $\left[\mathrm{GdCuL}^{2}(\mathrm{bpy})_{2}\right]$, (c) $\left[\mathrm{GdCuL}^{3}(\mathrm{bpy})_{2}\right]$, (d) $\left[\mathrm{GdCuL}^{4}(\mathrm{bpy})\right]$ and (e) $\left[\mathrm{GdCuL}^{5}(\mathrm{bpy})_{2}\right]$

Table 2. Electrochemical data for $\left[\mathrm{GdCuL}^{1-5}\left(\mathrm{NO}_{3}\right)(\mathrm{bpy})_{2}\right]$ complexes

\begin{tabular}{cccc}
\hline \multirow{2}{*}{ No } & \multirow{2}{*}{ Complexes } & \multicolumn{2}{c}{ Reduction (cathodic) potential } \\
\cline { 3 - 4 } & & $\mathrm{E}_{\mathrm{pc}}^{1}(\mathrm{~V})$ & $\mathrm{E}_{\mathrm{pc}}^{2}(\mathrm{~V})$ \\
\hline 1 & {$\left[\mathrm{GdCuL}^{1}\right]$} & -1.05 & -1.90 \\
2 & {$\left[\mathrm{GdCuL}^{2}\right]$} & -0.98 & -1.82 \\
3 & {$\left[\mathrm{GdCuL}^{3}\right]$} & -0.84 & -1.69 \\
4 & {$\left[\mathrm{GdCuL}^{4}\right]$} & -0.75 & -1.60 \\
5 & {$\left[\mathrm{GdCuL}^{5}\right]$} & -0.65 & -1.39 \\
\hline
\end{tabular}

\section{Magnetic behavior}

\section{Magnetic properties of complex 5: [ GdCuL $\left.{ }^{5}\left(\mathrm{NO}_{3}\right)(\text { bpy })_{2}\right]\left(\mathrm{ClO}_{4}\right)_{2}$}

The temperature $(T)$ dependence of magnetic susceptibility $\left(\chi_{\mathrm{m}}\right)$ in the range of $20-300 \mathrm{~K}$ is shown in Figure 6 . The effective magnetic moment $\left(\mu_{\text {eff }}\right)$ at $300 \mathrm{~K}$ is $7.78 \mu_{\mathrm{B}}$ obtained form the plot $\chi_{\mathrm{M}} T v s$. T. At $180 \mathrm{~K}$ the $\chi_{\mathrm{M}} T$ value is equal to $7.85 \mathrm{~cm}^{3} \mathrm{~K} \mathrm{~mol}^{-1}$, which roughly corresponds to the value expected for the two uncoupled metal ions. Lowering the temperature causes to increase the $\chi_{\mathrm{M}} T$ value to $10.5 \mathrm{~cm}^{3} \mathrm{~K} \mathrm{~mol}^{-1}$ at $20 \mathrm{~K}$. This value 
compares well with that $\left(10.5 \mathrm{~cm}^{3} \mathrm{~K} \mathrm{~mol}^{-1}\right)$ expected for the $\mathrm{S}=4$ spin state resulting from ferromagnetic coupling between $\mathrm{Gd}(\mathrm{III})(\mathrm{S}=7 / 2)$ and $\mathrm{Cu}(\mathrm{II})(\mathrm{S}=1 / 2)$ and assuming that very similar $\alpha_{\mathrm{Gd}}=\alpha_{\mathrm{Cu}}=2.0$. Data have been obtained. A quantitative analysis can be performed on the basis of a spin-only expression derived from a spin Hamiltonian $\mathrm{H}=-J S_{\mathrm{Cu}} S_{\mathrm{Gd}}$ taking into consideration that the two low-lying $\mathrm{H}=\mathrm{JS}_{\mathrm{Cu}} \mathrm{S}_{\mathrm{Gd}}$ levels $\mathrm{E}(4)=0$ and $\mathrm{E}(3)=4 \mathrm{~J}$ may have different $g$ values ${ }^{23},\left[\alpha_{4}=\left(7 \alpha_{\mathrm{Gd}}+\alpha_{\mathrm{Cu}}\right) / 8\right.$ and $\left.\mathrm{g}_{3}=\left(9 \alpha_{\mathrm{Gd}}-\alpha_{\mathrm{Cu}}\right) / 8\right]$, the experimental data are data using the expression. The resulting values of the parameters are $J=4.2 \mathrm{~cm}^{-1}$ and $\alpha_{\mathrm{Cu}}=$ $2.05, \alpha_{\mathrm{Gd}}=2.0 \mathrm{R}=\left[\left(\chi_{\mathrm{obs}} \mathrm{T}-\chi_{\mathrm{cal}} \mathrm{T}\right)^{2} /\left(\chi_{\mathrm{obs}} \mathrm{T}\right)^{2}\right] 3.9 \times 10^{-5}$ there is no doubt that the observed ferromagnetic behaviour is an intrinsic property of the core. The $\mathrm{J}$ values are slightly lower for $\mathrm{GdO}_{2} \mathrm{Cu}$ than those previously published for four structurally characterized hetero binuclear $(\mathrm{Cu}, \mathrm{Gd})$ complexes. The structural study of the complex shows that a third bridge joins an axial site of $\mathrm{Gd}$ to an axial site of $\mathrm{Cu}$ which has, at best, a very feeble spin density. The observed $\mathrm{J}$ value $\left(4.81 \mathrm{~cm}^{-1}\right)$ is quite similar to those found for complexes in which the magnetic interaction is mediated by a double bridge, $\mathrm{CuO}_{2} \mathrm{Gd}$ as in previous examples. Furthermore, the very nice fit obtained for Figure 6 with the help of the above expression corresponding to a binuclear $\mathrm{Gd}-\mathrm{Cu}$ complex confirms the binuclear character of the powdered sample.

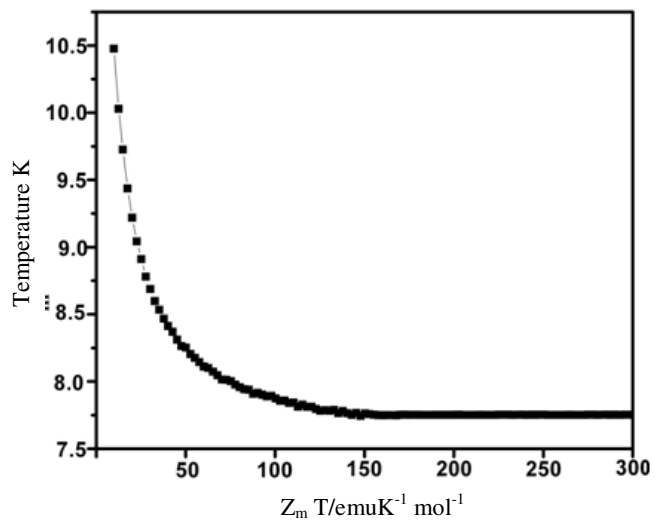

Figure 6. Thermal dependence of $\chi_{\mathrm{M}} T$ for $\left[\mathrm{GdCuL}^{5}(\mathrm{bpy})_{2}\right]$ at $0.5 \mathrm{~T}$.

( Full line corresponds to the best data fit)

\section{Kinetic Studies}

\section{Oxidation of pyrocatechol (Catecholase activity)}

The catecholase activity of the $\left[\mathrm{GdCuL}^{1-5}(\mathrm{bpy})_{2}\right]$ complexes synthesized in the present work was carried out using pyrocatechol as the convenient model substrate for the identification of functional models for the metalloenzymes ${ }^{24}$. For this purpose, $10^{-3} \mathrm{~mol} \mathrm{dm}^{-3}$ solutions of the complexes in dimethylformamide were treated with 100 equivalents of pyrocatechol in the presence of air. The course of the reaction was followed spectrophotometrically at $390 \mathrm{~nm}$ for nearly $45 \mathrm{~min}$ at regular time intervals of $5 \mathrm{~min}$. The slope was determined by the method of initial rates by monitoring the growth of the $390 \mathrm{~nm}$ band of the product $o$-quinone. A linear relationship for initial rate and the complex concentration obtained for $\left[\mathrm{GdCuL}^{1-5}(\mathrm{bpy})_{2}\right]$ complexes show a first-order dependence on the complex concentration for the systems.

Plots of $\log \left(\mathrm{A}_{\infty} / \mathrm{A}_{\infty}-\mathrm{A}_{\mathrm{t}}\right)$ vs. time for catecholase activity of the $\left[\mathrm{GdCuL}^{1-5}(\mathrm{bpy})_{2}\right]$ complexes are obtained and shown in Figure 7. The inset in Figure 7 shows the time 
dependent growth of $o$-quinone chromophore in the presence of $\left[\operatorname{GdCuL}^{5}(\mathrm{bpy})_{2}\right]$. The observed initial rate constant value for $\left[\mathrm{GdCuL}^{1-5}(\mathrm{bpy})_{2}\right]$ complexes is given in Table 3 . The complex $\left[\mathrm{GdCuL}^{5}(\mathrm{bpy})_{2}\right]$ has higher catalytic activity $\left(6.69 \times 10^{-3} \mathrm{~min}^{-1}\right)$ than the complex $\left[\mathrm{GdCuL}^{4}(\mathrm{bpy})_{2}\right]\left(5.72 \times 10^{-3} \mathrm{~min}^{-1}\right)$ which in turn is higher than the complex $\left[\mathrm{GdCuL}^{1}(\mathrm{bpy})_{2}\right]$ $\left(2.12 \times 10^{-3} \mathrm{~min}^{-1}\right)$. The order of activity of the complexes is shown below.

$\left[\mathrm{GdCuL}^{5}(\text { bpy })_{2}\right]>\left[\mathrm{GdCuL}^{4}(\text { bpy })_{2}\right]>\left[\mathrm{GdCuL}^{3}(\text { bpy })_{2}\right]>\left[\mathrm{GdCuL}^{2}(\text { bpy })_{2}\right]>\left[\mathrm{GdCuL}^{1}(\text { bpy })_{2}\right]$

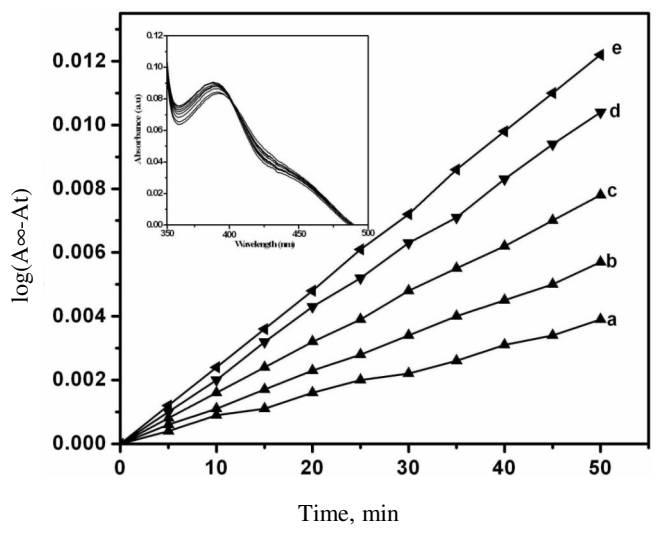

Figure 7. Catecholase activity of: $\left[\mathrm{GdCuL}^{1-5}(\mathrm{bpy})_{2}\right]$ (a) $\left[\mathrm{Gd} \mathrm{CuL}^{1}(\mathrm{bpy})_{2}\right]$, (b) $\left[\mathrm{GdCuL}^{2}\right.$ (bpy) $\left.)_{2}\right]$, (c) $\left[\mathrm{GdCuL}^{3}(\mathrm{bpy})_{2}\right],(\mathrm{d})\left[\mathrm{GdCuL}^{4}\right.$ (bpy)] and (e) $\left[\mathrm{GdCuL}^{5}(\mathrm{bpy})_{2}\right]$. The inset is the time dependent growth of $o$-quinine chromophore in the presence of $\left[\mathrm{GdCuL}^{5}\left(\mathrm{NO}_{3}\right)\right]$.

Table 3. Catecholase activity $\left[\mathrm{GdCuL}^{1-5}(\mathrm{bpy})_{2}\left(\mathrm{NO}_{3}\right)\right]$

\begin{tabular}{ccc}
\hline No & Complexes & $\begin{array}{c}\text { Rate constant }(\mathrm{k}) \\
\left(\times 10^{-3}\right) \mathrm{min}^{-1} \text { catecholase }\end{array}$ \\
\hline 1 & {$\left[\mathrm{GdCuL}^{1}\right]$} & 2.12 \\
2 & {$\left[\mathrm{GdCuL}^{2}\right]$} & 3.61 \\
3 & {$\left[\mathrm{GdCuL}^{3}\right]$} & 4.32 \\
4 & {$\left[\mathrm{GdCuL}^{4}\right]$} & 5.72 \\
5 & {$\left[\mathrm{GdCuL}^{5}\right]$} & 6.69 \\
\hline
\end{tabular}

From the results it is observed that the rate of oxidation of catecholase to $o$-quinone has increased as the chain length increases. The catecholase activity of complex containing longer carbon chain in the imine compartment is higher than that of the complex containing lesser carbon chain in the imine compartment, which is due to flexibility resulting from distortion of the coordination sphere. Increase in the chain length causes a greater distortion of the geometry of the complexes. This geometry may favour the observed higher rate of the reaction.

\section{DNA binding and cleavage studies}

\section{Absorption spectral studies}

The binding ability of complexes $\left[\mathrm{GdCuL}^{1}(\mathrm{bpy})_{2}\right], \quad\left[\mathrm{GdCuL}^{2}(\mathrm{bpy})_{2}\right], \quad\left[\mathrm{GdCuL}^{3}(\mathrm{bpy})_{2}\right]$ $\left[\mathrm{GdCuL}^{4}(\mathrm{bpy})_{2}\right]$ and $\left[\mathrm{GdCuL}^{5}(\mathrm{bpy})_{2}\right]$ with calf thymus (CT) DNA is characterized by measuring their effects on the UV spectra. Complex binding with DNA through intercalation usually result in bathochromism due to the intercalative mode involving a strong stacking interaction between an aromatic chromophore and the base pairs of DNA ${ }^{25}$. In the present investigation the interaction of the bipyridyl based binuclear $\left[\mathrm{GdCuL}^{1}(\mathrm{bpy})_{2}\right],\left[\mathrm{GdCuL}^{2}\right.$ (bpy $\left.)_{2}\right],\left[\mathrm{GdCuL}^{3}(\mathrm{bpy})_{2}\right]\left[\mathrm{GdCuL}^{4}(\mathrm{bpy})_{2}\right]$ and $\left[\mathrm{GdCuL}^{5}(\mathrm{bpy})_{2}\right]$ complexes with CT DNA 
have been investigated. Absorption titration experiments of the $\mathrm{Gd}(\mathrm{III}) \mathrm{Cu}(\mathrm{II})$ complexes in buffer were performed by using a fixed concentration to which gradually increments of the DNA $(10 \mathrm{mM})$ stock solution were added at $25{ }^{\circ} \mathrm{C}$. The binding of the complexes to duplex DNA led to a decrease in the absorption intensities with a small amount of red shift in the $\mathrm{UV}-\mathrm{Vis}$ absorption spectra. After intercalating the base pairs of DNA, the $\pi^{*}$ orbital of the intercalated ligand can couple with the $\pi$ orbital of the base pairs, thus decreasing the $\pi-\pi^{*}$ transition energy and resulting in the bathochromism ${ }^{26}$.

To compare quantitatively the affinity of the complexes toward DNA, the binding constant $\mathrm{K}$ of the complexes to CT DNA was determined by monitoring the changes in the absorbance of charge transfer spectral band near at $230 \mathrm{~nm}, 280 \mathrm{~nm}$ and $350 \mathrm{~nm}$ for the complex $\left[\mathrm{GdCuL}^{2}(\mathrm{bpy})_{2}\right]$, near $233 \mathrm{~nm}, 275 \mathrm{~nm}$ and $375 \mathrm{~nm}$ for the complex $\left[\mathrm{GdCuL}^{3}\right.$ $(\text { bpy })_{2}$ ], near $263 \mathrm{~nm}, 283 \mathrm{~nm}, 310 \mathrm{~nm}$ and $360 \mathrm{~nm}$ for the complex of [GdCuL $\left.{ }^{4}(\mathrm{bpy})_{2}\right]$ and at $212 \mathrm{~nm}, 243 \mathrm{~nm}, 281 \mathrm{~nm}, 317 \mathrm{~nm}$, for the complex of [GdCuL $\left.{ }^{5}(\mathrm{bpy})_{2}\right]$. The spectroscopic titration of the complexes was shown in Figure 8. DNA binding constant value given in Table 4. The extent of hypochromism gives a measure of the strength of the intercalative binding. The observed trend in hypochromism among the present complexes follows the order bipyridyl based binuclear $(\mathrm{GdCu})$. The intrinsic binding constants $\mathrm{K}_{\mathrm{b}}$ of the four complexes with CT DNA were determined according to the following equation.

$$
\left.[\mathrm{DNA}] /\left(\varepsilon_{\mathrm{a}}-\varepsilon_{\mathrm{f}}\right)\right)=[\mathrm{DNA}] /\left(\varepsilon_{\mathrm{b}}-\varepsilon_{\mathrm{f}}\right)+1 / \mathrm{K}_{\mathrm{b}}\left(\varepsilon_{\mathrm{b}}-\varepsilon_{\mathrm{f}}\right)
$$

Where [DNA] is the concentration of DNA in base pairs, the apparent absorption coefficients $\varepsilon_{\mathrm{a}}, \varepsilon_{\mathrm{f}}$ and $\varepsilon_{\mathrm{b}}$ correspond to $\mathrm{A}_{\text {obsd }} /\left[\mathrm{M}_{2}\right]$, the extinction coefficient for the free complexes and the extinction coefficient for the complexes in the fully bound form, respectively. In plots of [DNA] / $\left(\varepsilon_{\mathrm{b}}-\varepsilon_{\mathrm{f}}\right)$ versus [DNA], $\mathrm{K}_{\mathrm{b}}$ is given by the ratio of the slope to the intercept.

The fluorescence spectroscopic technique is an effective method to study metal interaction with DNA. Ethidium bromide (EB) is one of the most sensitive fluorescence probes that can bind with $\mathrm{DNA}^{27}$. The fluorescence of EB increases after intercalating into DNA. If the metal intercalates into DNA, it leads to a decrease in the binding sites of DNA available for EB, resulting in a decrease in the fluorescence intensity of the EB-DNA system ${ }^{28}$. The emission spectra of EB bound to DNA in the absence and presence of the complexes [ $\left.\mathrm{GdCuL}^{1}(\mathrm{bpy})_{2}\right]$, $\left[\mathrm{GdCuL}^{2}(\mathrm{bpy})_{2}\right],\left[\mathrm{GdCuL}^{3}(\mathrm{bpy})_{2}\right],\left[\mathrm{GdCuL}^{4}(\mathrm{bpy})_{2}\right]$ and $\left[\mathrm{GdCuL}^{5}(\mathrm{bpy})_{2}\right]$, are shown in Figure 9 DNA binding constant value given in Table 4. Fluorescence intensities at $610 \mathrm{~nm}(510 \mathrm{~nm}$ excitation) were measured at different complex concentrations. A $2 \mathrm{~mL}$ solution of $40 \mu \mathrm{M}$ DNA and $0.66 \mu \mathrm{M}$ of ethidium bromide (EB, at saturation binding level) was titrated with 0$80 \mu \mathrm{M}$ metal complexes at $25^{\circ} \mathrm{C}$. The addition of the complex to DNA pretreated with EB causes an appreciable reduction in the fluorescence intensity, indicating that complex competes with EB to bind with DNA. The reduction of the emission intensity gives a measure of the DNA binding propensity of the complexes and stacking interaction (intercalation) between adjacent DNA base pairs ${ }^{29}$. The fluorescence quenching curve of DNA-bound EB by complexes illustrates that the quenching of EB bound to DNA by complexes is in good agreement with the linear Stern-Volmer equation.

\section{Fluorescence spectral studies}

$$
\mathrm{I}_{0} / \mathrm{I}=+\mathrm{K}_{\mathrm{sv}}[\mathrm{Q}]
$$

In the linear fit plot of $\mathrm{I}_{0} / \mathrm{I}$ versus [complex]/[DNA], $\mathrm{K}_{\mathrm{sv}}$ is given by the ratio of the slope to the intercept. $\mathrm{I}_{0}$ is the emission intensity of EB-DNA in the absence of the complex; $\mathrm{I}$ is the emission intensity of EB-DNA in the presence of complex. 


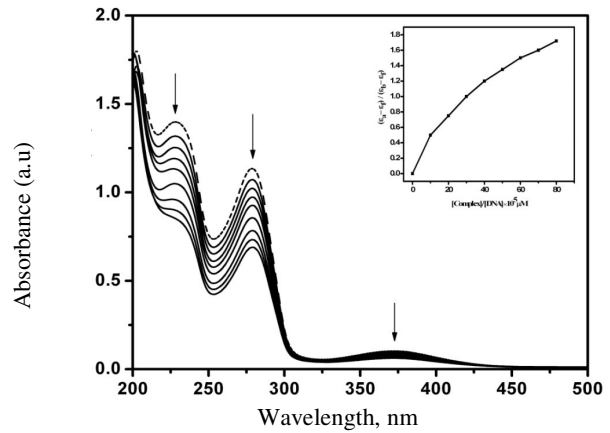

Figure 8. Absorption spectra of complex $\left[\mathrm{GdCuL}^{5}(\mathrm{bpy})_{2}\right](20 \mu \mathrm{M})$ in the presence of increasing quantity of CT DNA; $0-80 \mu \mathrm{M}$. (The arrow shows the absorbance change upon increasing DNA concentrations. Insets shows the plot of $\left(\varepsilon_{a}-\varepsilon_{f}\right) /\left(\varepsilon_{b}-\varepsilon_{f}\right)$ vs. [DNA] for the titration of DNA with the complex).

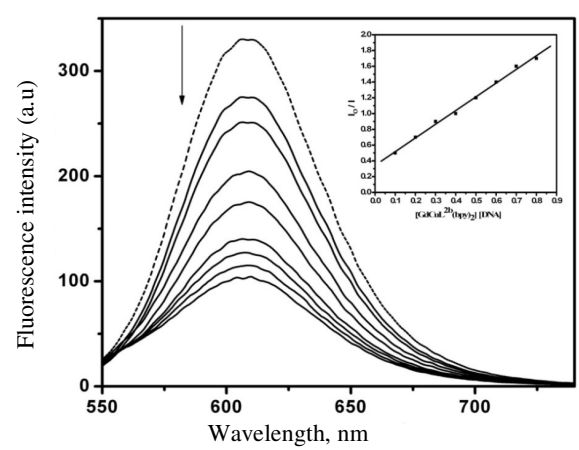

Figure 9. Emission spectrum of $\mathrm{EtBr}$ bound to DNA system $([\mathrm{EtBr}]=3.3 \mu \mathrm{M}$, $[\mathrm{CD}$ DNA $]=80 \mu \mathrm{M},\left[\mathrm{GdCuL}^{2}(\mathrm{bpy})_{2}\right]=0$ $80 \mu \mathrm{M}, \lambda_{\mathrm{emi}}=510 \mathrm{~nm}$ ). (The arrow shows the intensity change upon increasing $\left[\begin{array}{ll}G d C u L^{5} & \left.(b p y)_{2}\right] \\ \end{array}\right]$ concentrations. Inset shows the plot of emission intensity Io / I vs. [complex] / [DNA])

Table 4. DNA binding constant of binuclear $\left[\mathrm{GdCuL}^{1-5}(\mathrm{bpy})_{2}\left(\mathrm{NO}_{3}\right)\right]$ complexes

\begin{tabular}{ccc}
\hline Complexes & $\begin{array}{c}\mathrm{K}_{\mathrm{b}}\left(\mathrm{M}^{-1}\right) \\
\text { Absorbance }\end{array}$ & $\begin{array}{c}\mathrm{K}_{\mathrm{b} \text { (app) }}\left(\mathrm{M}^{-1}\right) \\
\text { Emission }\end{array}$ \\
\hline$\left[\mathrm{GdCuL}^{1}(\mathrm{bpy})_{2}\right]$ & $2.96 \times 10^{5}$ & $1.67 \times 10^{6}$ \\
{$\left[\mathrm{GdCuL}^{2}(\mathrm{bpy})_{2}\right]$} & $3.11 \times 10^{5}$ & $2.14 \times 10^{6}$ \\
{$\left[\mathrm{GdCuL}^{3}(\mathrm{bpy})_{2}\right]$} & $3.20 \times 10^{5}$ & $2.26 \times 10^{6}$ \\
{$\left[\mathrm{GdCuL}^{4}(\mathrm{bpy})_{2}\right]$} & $3.32 \times 10^{5}$ & $2.39 \times 10^{6}$ \\
{$\left[\mathrm{GdCuL}^{5}(\mathrm{bpy})_{2}\right]$} & $3.54 \times 10^{5}$ & $2.59 \times 10^{6}$ \\
\hline
\end{tabular}

DNA cleavage study for [ $\left.G d C u L^{1-5}(\text { bpy })_{2}\right]$ complexes

With the $\left[\mathrm{GdCuL}^{1-5}(\mathrm{bpy})_{2}\right]$ complexes there was an increase in the incubation time of room temperature which leads to the cleavage efficiency was increased. Its reported that the binding activity of ligands with DNA was efficient. A notable similarity of expression is obtained for all the chemical complexes through all the complexes cleave DNA by formation of cleaved bands Agarose Gel electrophoresis photograph are given in Figure 10. So we can bring those compounds for further medication studies. In this work we present the successful application of in vitro screening based on the DNA cleavage. Complex $\left[\mathrm{GdCuL}^{1}(\mathrm{bpy})_{2}\right]$ and $\left[\mathrm{GdCuL}^{4}(\mathrm{bpy})_{2}\right]$ exhibits pronounced bioactivity in vitro infection experiments compares with other ligand whether it may be the activity based on saturation condition or position of the ligand ${ }^{30-34}$. These results confirm the applicability of complex activity on infectious organisms. This preliminary study offers rich opportunity for complex activity on in vitro studies and identification of various bioactive chemotypes. These inhibitory studies will help to gain new insights into the relationship between bacterial vectors with $\left[\mathrm{GdCuL}^{1-5}(\mathrm{bpy})_{2}\right]$ complexes on the molecular level.

\section{Antimicrobial activity}

Antimicrobial activity of the synthesized binuclear complexes $\left[\mathrm{GdCuL}^{1-5}(\mathrm{bpy})_{2}\left(\mathrm{NO}_{3}\right)\right]$, against five tested microorganisms has been studied. As per the recorded data for all the 
$\left[\mathrm{GdCuL}^{1-5}(\mathrm{bpy})_{2}\left(\mathrm{NO}_{3}\right)\right]$ binuclear complexes show different effects against the different organisms showing highest activity against Klebsiella sp and at the concentration of $125 \mu \mathrm{M}$. Complex $\left[\mathrm{GdCuL}^{1}(\mathrm{bpy})_{2}\right]$ and $\left[\mathrm{GdCuL}^{5}(\mathrm{bpy})_{2}\right]$, have the highest antimicrobial activity against all the organisms, In contrast $\left[\operatorname{GdCuL}^{3}(\mathrm{bpy})_{2}\right]$, showed the lowest activity. This difference might be due to different structure of $\left[\mathrm{GdCuL}^{1-5}(\mathrm{bpy})_{2}\right]$ complexes, activity of side chains i.e. difference in binding sight of ligands with the molecules ${ }^{35-37}$

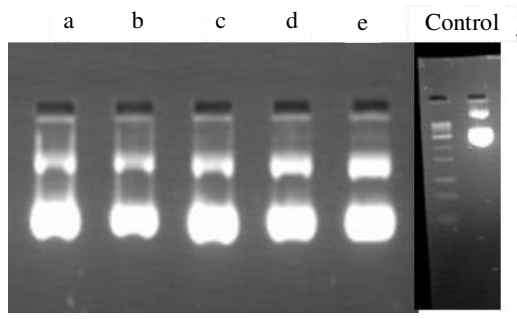

Figure 10. Agarose gel electrophoresis photograph of the super coiled pBR322 DNA treated with different complexes $\left[\mathrm{GdCuL}^{1-5}(\mathrm{bpy})_{2}\right]$. (Lane1: Control; Lane (a): pBR322 DNA treated with $100 \mu \mathrm{M}$ of $\left[\mathrm{GdCuL}^{\mathrm{I}}(\mathrm{bpy})_{2}\right]$ complex; Lane (b): pBR322 DNA treated with $100 \mu \mathrm{M}$ of [GdCuL ${ }^{2}(\text { bpy })_{2}$ ] complex; Lane (c): pBR322 DNA treated with $100 \mu \mathrm{M}$ of $\left[\mathrm{GdCuL}^{3}(\text { bpy })_{2}\right]$ complex; Lane (d): pBR322 DNA treated with $100 \mu \mathrm{M}$ of [GdCuL $\left.L^{4}(\text { bpy })_{2}\right]$ complex; Lane (e): pBR322 DNA treated with $100 \mu \mathrm{M}$ of $\left[\mathrm{GdCuL}^{5}(\text { bpy })_{2}\right]$ complex; Form I and II represents Supercoiled, Nicked circular and Linear form of pBR 322 DNA respectively).

\section{Conclusion}

We have synthesized and characterized five d-f heterobinuclear $\mathrm{Gd}(\mathrm{III}) \mathrm{Cu}(\mathrm{II})$ complexes. All the d-f hetrobinuclear $\mathrm{Gd}(\mathrm{III}) \mathrm{Cu}(\mathrm{II})$ complexes have better antimicrobial activity against gram positive and gram negative pathogens. The electronic spectra of [ $\mathrm{Gd}(\mathrm{III}) \mathrm{Cu}(\mathrm{II}) \mathrm{L}^{1-5}$ ] complexes have red shift in the spectra is due to the increase in chain length. Electronic absorption and fluorescence spectra measurements of $\left[\mathrm{Gd}(\mathrm{III}) \mathrm{Cu}(\mathrm{II}) \mathrm{L}^{5}\left(\mathrm{NO}_{3}\right)\right]$ complex indicates strong binding with CT DNA, presumably via intercalation. Catalytic activity increases due to increase of methylene groups around the metal.

\section{Acknowledgement}

Financial support from the CSIR New Delhi is gratefully acknowledged and National Centre for Ultrafast Process, University of Madras, for the fluorescence and lifetime measurements.

\section{References}

1. Karipcin F, Dede B, Caglar Y, Hür D, Ilican S, Caglar M and Sahin Y, Opt Commun., 2007, 272, 131-137.

2. Rey N A, Neves A, Bortoluzzi A, Pich C T and Terenzi H, Inorg Chem., 2007, 46, 348.

3. Maxim C, Pasatoiu T D, Ch Kravtsov V, Shova S, Muryn C A, Winpenny R E P, Tuna F and Andruh M, Inorg Chim Acta, 2008, 361, 3903.

4. Anbu S, Kandaswamy M, Suthakaran P, Murugan V and Varghese B, J Inorg Biochem., 2009, 103, 401-410.

5. Siebert R, Winter A, Dietzek B and Schubert U S, J Macromol Rapid Commun., 2010, 31, 883-888.

6. Siebert R, Winter A, Schubert U S, Dietzek B and Popp J, J Phys Chem., 2010, 114, 6841.

7. Oyoshi T and Sugiyama H, J Am Chem Soc., 2000, 122, 6313-6314. 
8. Wu M, Stoermer D, Tullius T D and Townsend C A, J Am Chem Soc., 2000, 122, 12884.

9. Oliveira M C B, Couto M S R, Severino P C, Foppa T, Martins G T S, Szpoganicz B, Peralta R A, Neves A and Terenzi H, Polyhedron, 2005, 24(4), 495-499.

10. Vijayaraj A, Prabu R, Suresh R, Sangeetha Kumari R, Kaviyarasan V and Narayanan V, Bull Korean Chem Soc., 2012, 33(11), 3581-3588.

11. Duff J C, J Chem Soc., 1941, 547-550.

12. Carnall W T, Siegel S, Ferraro J R, Tani B and Gebert E, Inorg Chem., 1973, 12, 560.

13. Khera B, Sharma A K and Kaushik N K, Polyhedron, 1983, 2(11), 1177-1180.

14. Nakamoto K, Infrared and Raman Spectra of Inorganic and Coordination Compounds, Wiley-Interscience, New York, $3^{\text {rd }}$ Edn., 1978.

15. Bagherzadeh M and Amini M, J Coord Chem., 2010, 63, 3849-3858.

16. Li X, Wanyan H, Dong W and Yang R, Polyhedron, 1993, 12(16), 2021-2025.

17. Karlin K D, Cohenn B I, Hayes J C and Farooq A, J Zubieta Inorg Chem., 1987, 26, 147-153.

18. Bhaumic M L and El-Sayed M A, J Phys Chem., 1965, 69, 275.

19. Dawson W R, Kropp J L and Windsor M W, J Chem Phys., 1966, 45(7), 2410.

20. Sakamoto M, Yamarnoto K, Matsumoto A, Nishida Y and Okawa H, Bull Chem Soc Jpn., 1994, 67, 2707.

21. Sakamoto M, Ohsaki M, Yamamoto K, Nakayama Y, Matsumoto A and Okawa H, Bull Chem Soc Jpn., 1992, 65, 2514.

22. Aime S, Bettinelli M, Ferrari M, Razzano E and Terreno E, Biochimica et Biophysica Acta, 1998, 1385, 7.

23. Costes J P, Dahan F, Dupuis A and Laurent J P, New J Chem., 1998, 22, 1525.

24. Sreedaran S, Shanmuga Bharathi K, Kalilur Rahiman A, Jagadish L, Kaviyarasan V and Narayanan V, Polyhedron, 2008, 27, 2931-2938.

25. Rompel A, Fischer H, Meiwes D, Karentzopoulos K B, Diillinger K, Tuczek F, Witzel H and Krebs B, J Biol Inorg Chem., 1999, 4, 56-63.

26. Peng B, Chao H, Sun B, Li H, Gao F and Ji L N, J Inorg Biochem., 2006, 100(9), 1487-1494.

27. Sasmal P K, Patra A K, Nethaji M and Chakravarty A R, Inorg Chem., 2007, 46(26), 11112-11121.

28. Nyarko E, Hanada N, Habib A and Tabata M, Inorg Chim Acta, 2004, 357, 739-745.

29. Lepecq J B and Paoletti C, J Mol Biol., 1967, 27(1), 87-106.

30. Bing B and Zhou S, Michael P, Biao H, Changnian L, Luc G, Eian C, Yvonne L, Frederic B, Iwao M, Noemi R, Gengjie Y, Yanlong L, Wenqing Y, Kris V, Adi F G, Steven M F, David M J, Robert C N, Jordan S F, John D M, Peggy A S, Cancer Cell, 2006, 10(1), 39-50.

31. Sugiyama H and Saito I, J Am Chem Soc., 1996, 118, 7063-7068.

32. Schmidt R, Daniel G, Volker H and Jürgen B, J Phys Chem A, 2005, 109(23), 50005004.

33. Mettath S, Benjamin R M and Ravindra K P, Bioconjugate Chem., 1999, 10(1), 94102.

34. Spada S, Biol Chem., 1997, 378, 445.

35. Arfa A B, Combes S, Preziosi-Belloy L, Gontard N and Chalier P, Lett Appl Microbiol., 2006, 43(2), 149-154.

36. Almeida A A, Almeida, Adriana Farah, Daniela A M Silva, Elzíria A Nunan, and Beatriz M A Glória, J Agri Food Chem., 2006, 54(23), 8738-8743.

37. Modak B, Torres R, Wilkens M and Urzúa A, J Chil Chem Soc., 2004, 49(1), 1-3. 